\title{
PENGARUH CURRENT RATIO, INVENTORY TURNOVER, TIME INTEREST EARNED DAN RETURN ON EQUITY TERHADAP HARGA SAHAM PADA PERUSAHAAN MANUFAKTUR SEKTOR BARANG KONSUMSI YANG TERDAFTAR DI BEI PERIODE 2009-2012
}

\author{
Indra Setiyawan \\ Prodi Akuntansi Universitas Negeri Yogyakarta \\ Setiyawan.indra07@gmail.com \\ Drs. Pardiman \\ Staf Pengajar P. Akuntansi Universitas Negeri Yogyakarta
}

\begin{abstract}
Abstrak: Penelitian ini bertujuan untuk mengetahui pengaruh dari Current Ratio, Inventory Turnover, Time Interest Earned dan Return On Equity terhadap Harga Saham pada perusahaan manufaktur sektor barang konsumsi yang terdaftar di BEI periode 2009-2012, baik secara parsial maupun secara simultan. Teknik analisis data yang digunakan yaitu uji asumsi klasik, regresi linear sederhana dan regresi linear berganda. Hasil penelitian menunjukan bahwa Current Ratio berpengaruh positif dan signifikan terhadap Harga Saham yang dibuktikan dengan nilai koefisien regresi sebesar 1,676 , nilai $t_{\text {hitung }}(2,469)>\mathrm{t}_{\text {tabel }}(1,675)$ dan nilai signifikansi $0,017<0,05$. Inventory Turnover berpengaruh negatif dan tidak signifikan terhadap Harga Saham yang dibuktikan dengan nilai koefisien regresi sebesar $-0,584$, nilai $t_{\text {hitung }}(-1,365)<t_{\text {tabel }}(1,675)$ dan nilai signifikansi $0,178>0,05$. Time Interest Earned berpengaruh positif dan signifikan terhadap Harga Saham yang dibuktikan dengan nilai koefisien regresi sebesar 1,176 , nilai $t_{\text {hitung }}(2,568)>t_{\text {tabel }}(1,675)$ dan nilai signifikansi $0,000<0,05$. Return On Equity berpengaruh positif dan signifikan terhadap Harga Saham yang dibuktikan dengan nilai koefisien regresi sebesar 0,799 , nilai $t_{\text {hitung }}(3,881)>t_{t a b e l}(1,675)$ dan nilai signifikansi 0,000 < 0,05. Current Ratio, Inventory Turnover, Time Interest Earned dan Return On Equity secara simultan berpengaruh signifikan terhadap Harga Saham yang dibuktikan dengan nilai $\mathrm{F}_{\text {hitung }}(8,332)>\mathrm{F}_{\text {tabel }}(2,56)$ dan nilai signifikansi $0,000<0,05$.
\end{abstract}

Abstract: The Purposes of this research are to find out the influences of Current Ratio, Inventory Turnover, Time Interest Earned and Return On Equity on the Stock Prices of consumer goods sector in manufacturer listed in IDX period 2009-2012, both partially and simultaneuosly. Data analysis techniques used in this research are classical assumption test, simple linear regression and mutiple regression. The results show that Current Ratio has positive and significant influence on the Stock Prices proven by coefficient regression value 1,676 , the value of $t_{\text {count }}(2,469)>t_{\text {tablel }}(1,675)$ and significant value 0,017 <0,05. Inventory Turnover has negative and insignificant influence on the Stock Prices evidenced by coefficient regression value $-0,584$, value of $t_{\text {count }}(-1,365)<t_{\text {table }}(1,675)$ and significant value 0,178 >0,05. Time Interest Earned has positive and significant influence on the Stock Prices verified by coefficient regression value 1,176 , value of $t_{\text {count }}(2,568)>t_{\text {table }}(1,675)$ and significant value 0,000 <0,05. Return On Equity has positive and significant influence on the Stock Prices evidenced by coefficient regression value 0,799, value of $t_{\text {count }}(3,881)>t_{\text {table }}(1,675)$ and significant 0,000 $<0,05$. Simultaneous Current Ratio, Inventory Turnover, Time Interest Earned and Return On Equity affects the Stock Prices singnificanly evidenced by the value of $F_{\text {count }}(8,332)>F_{\text {table }}$ $(2,56)$ and significant value $0,000<0,05$.

Keywords: Stock Price, Current Ratio, Inventory Turnover, Time Interest Earned, Return On Equity 


\section{JURNAL NOMINAL / VOLUME III NOMOR 2 / TAHUN 2014}

\section{PENDAHULUAN}

Pasar modal adalah tempat bertemunya antara pihak yang memiliki kelebihan dana dengan pihak yang membutuhkan dana dengan cara memperjualbelikan sekuritas (Tandelilin, 2007:13). Menurut Mohamad Samsul (2006: 43), "pasar modal merupakan tempat bertemunya permintaan dan penawaran instrumen keuangan jangka panjang”. Instrumen keuangan jangka panjang yang bisa digunakan investor sebagai pilihan berinvestasi diantaranya yaitu saham, obligasi, reksadana, instrumen derivatif (opsi dan futures). Diantara instrumen pasar modal diatas yang paling populer adalah saham.

Saham adalah surat bukti kepemilikan atas suatu perusahaan (Tandelilin, 2007: 18). Saham lebih populer dan mampu menarik perhatian investor dikarenakan saham menjanjikan imbal hasil yang lebih tinggi dibanding instrumen lainya. Imbal hasil atas kepemilikan suatu saham bisa berupa dividen dan capital gain. Disamping terdapat imbal hasil yang tinggi, disisi lain saham juga mempunyai risiko yang tidak bisa diabaikan. Semakin tinggi imbal hasil yang diharapkan semakin tinggi pula risiko yang akan dihadapi seorang investor. Berdasarkan hal tersebut, investor harus jeli dan memperhitungkan baik-baik sebelum berinvestasi dalam saham.

Salah satu hal yang harus menjadi fokus pertimbangan seorang investor adalah Harga
Saham. Harga Saham yang diharapkan oleh investor adalah Harga Saham yang stabil dan mempunyai pola pergerakan yang cenderung naik dari waktu ke waktu, akan tetapi kenyataanya Harga Saham cenderung berfluktuasi. Berfluktuasinya Harga Saham menjadi risiko tersendiri bagi investor. Oleh karena itu investor harus memahami hal apa saja yang dapat mempengaruhi fluktuasi Harga Saham.

Fluktuasi Harga Saham secara fundamental dipengaruhi oleh kinerja perusahaan dan kemungkinan risiko yang dihadapi perusahaan (Mohamad samsul, 2006: 200). Kinerja perusahaan dapat tercermin dari laba operasional, laba bersih per saham dan rasio-rasio keuangan yang menggambarkan kemampuan manajemen dalam mengelola perusahaan. Rasio keuangan yang dapat digunakan untuk mengukur kinerja perusahaan diantaranya yaitu rasio likuiditas, rasio manajemen asset, rasio leverage dan rasio profitabilitas. Menurut Brigham (2012:150), apabila nilai keempat rasio tersebut diatas terlihat baik dan berjalan terus menerus secara stabil maka Harga Saham kemungkinan akan tinggi. Masing-masing contoh dari keempat rasio diatas adalah Current Ratio, Inventory Turnover, Time Interest Earned dan Return On Equity.

Current Ratio (CR) adalah salah satu rasio yang mengukur tingkat likuiditas perusahaan dengan cara membandingkan 


\section{JURNAL NOMINAL / VOLUME III NOMOR 2 / TAHUN 2014}

aset lancar dengan hutang lancar. Menurut (Brigham, 2012: 134) CR merupakan sebuah rasio likuiditas yang menunjukan sampai sejauh apa kewajiban lancar ditutupi oleh aset yang diharapkan akan dikonversi menjadi kas dalam waktu dekat. Invesor dapat menggunakan rasio ini untuk mengukur kemampuan perusahaan dalam menutup hutang lancarnya dengan aset lancar yang dimiliki.

Inventory Turnover (ITO) adalah rasio manajemen aset atau rasio aktivitas yang menunjukan tingkat perputaran persediaan perusahaan selama satu tahun. Menurut Wild (2005: 200) "ITO adalah rasio yang mengukur kecepatan rata-rata persediaan bergerak keluar dari perusahaan”. ITO akan memberi informasi kepada investor tentang seberapa baik perusahaan mengelola aset perusahaan berupa persediaan.

Time Interest Earned (TIE) adalah rasio utang (leverage) yang menunjukan kemampuan perusahaan membayar bunga atas hutangnnya selama setahun dengan laba yang dihasilkan. Menurut Brigham (2012: 144) "TIE merupakan rasio yang mengukur sampai sejauh apa laba operasi dapat mengalami penurunan sebelum perusahaan tidakmampu memenuhi biaya bunga tahunanya". TIE akan memberi informasi kepada investor tentang seberapa baik perusahaan membayar beban bunga tahunanya. TIE yang rendah menunjukan kemampuan yang jelek dari perusahaan dalam melunasi beban bunga. Apabila TIE semakin turun secara terus menerus maka akan menyebabkan masalah dan berujung pada kegagalan membayar bunga.

Return On Equity (ROE) didefinisikan Tandelilin (2007: 240) sebagai sebuah rasio profitabilitas yang menggambarkan sejauhmana kemampuan perusahaan menghasilkan laba yang bisa diperoleh pemegang saham. Menurut Brigham (2006: 109) "ROE merupakan suatu rasio akuntansi yang paling penting bagi investor". Pendapat ini didasarkan atas pemahaman bahwa investor berinvestasi untuk mendapatkan penegembalian atas uang mereka, dan rasio ROE menggambarkan seberapa baik perusahaan telah melakukan hal tersebut.

Analisis kinerja perusahaan dengan rasio keuangan seperti yang telah dikemukan diatas memang akan membantu investor untuk memilih perusahaan yang mempunyai prospek baik dan mendatangkan keuntungan, akan tetapi tidak semua jenis perusahaan dapat dibandingkan dengan analisis rasio tersebut. Analisis rasio hanya akan memberikan hasil yang berarti jika dibandingkan antar perusahaan (industri) sejenis. Hal ini dikarenakan baik buruknya nilai dari rasio tersebut sangat bergantung dari jenis industrinya.

Salah satu jenis industri yang ada di BEI adalah industri manufaktursektor barang konsumsi. Sektor industri barang 


\section{JURNAL NOMINAL / VOLUME III NOMOR 2 / TAHUN 2014}

konsumsi merupakan industri yang memproduksi berbagai jenis kebutuhan konsumsi masyarakat. Sektor industri barang konsumsi terdiri dari beberapa subsektor yaitu, subsektor makanan dan minuman, rokok, farmasi, kosmetik dan keperluan rumah tangga, dan peralatan rumah tangga. Produk yang dihasilkan sektor industri ini merupakan kebutuhan sehari-hari manusia sehingga dianggap sebagai sektor yang tangguh dalam menghadapi krisis. Selain itu jumlah penduduk indonesia yang besar,dimana mencapai 200 juta lebih membuat industri barang konsumsi mempunyai pangsa pasar yang besar dan mempunyai prospek bisnis yang bagus.

Perumbuhan industri barang konsumsi di indonesia menunjukan nilai yang menggembirakan dalam beberapa tahun terakhir. Data BAPEPAM-LK (2012) menunjukan bahwa industri barang konsumsi terus tumbuh dan semakin diminati. Hal itu dapat terlihat dari pertumbuhan indeks sektoral barang konsumsi yang tumbuh secara signifikan dibanding sektor lainya. Sebelum tahun 2009 menunjukan angka pertumbuhan yang cenderung menurun, namun mulai tahun 2009-2012 pertumbuhan indeks sektoral barang konsumsi cenderung naik drastis. Selain pertumbuhan yang cukup bagus, industri barang konsumsi di Indonesia juga merupakan salah satu penyumbang terbesar
Pendapatan Domestik Bruto (PDB) dari industri nonmigas. Pada tri wulan II/2012 bahkan produk barang konsumsi harian mampu mendorong pertumbuhan ekonomi Indonesia menjadi yang terbesar kedua di dunia. Walaupun pertumbuhan industri sektor barang konsumsi bagus dan manjadi salah satu penyumbang PDB terbesar, sektor barang konsumsi juga tidak terlepas dari berbagai permasalahan yang harus diselesaikan agar tidak menghambat pertumbuhannya.

Berdasarkan uraian diatas maka akan dilakukan penelitian mengenai pengaruh rasio keuangan yang digambarkan dengan rasio CR, ITO, TIE dan ROE terhadap Harga Saham industri barang konsumsi tahun 2009-2012. Tahun 2009-2012 dipilih sebagai periode penelitian dikarenakan pada tahun tersebut indeks harga saham sektoral barang konsumsi, menunjukan pertumbuhan yang signifikan dibanding sektor lainya.

\section{METODE PENELITIAN}

\section{Jenis Penelitian}

Penelitaian ini merupakan penelitian kausal-komparatif. Kausal komparatif adalah penelitian yang berusaha menguraikan peristiwa yang telah terjadi dengan menelisik kebelakang untuk mengetahui faktor-faktor yang menyebabkan peristiwa tersebut terjadi. 


\section{Tempat dan Waktu Penelitian}

Penelitian dilakukan di Bursa Efek Indonesia dengan mengambil data perusahaan barang konsumsi yang terdapat di website resmi Bursa Efek Indonesia. Pengambilan data dilakukan pada bulan Januari- Februari 2014

\section{Definisi Operasional Variabel Penelitian}

\section{a. Variabel Dependen}

Variabel dependen dalam penelitian ini adalah Harga Saham. Harga Saham adalah harga suatu saham yang terjadi di pasar bursa pada saat tertentu yang ditentukan oleh mekanisme pasar berupa permintaan dan penawaran saham tersebut (Jogiyanto, 2010: 130). Harga Saham yang digunakan dalam penelitian ini adalalah Harga Saham penutupan (Closing price) yang di indekskan atau lebh sering disebut Index Harga Saham Individual (IHSI). IHSI dapat diukur dengan rumus sebagai berikut :

$$
\text { IHSI }=\frac{\text { Harga pasar per unit }}{\text { Nilai dasar per unit }} \times 100
$$

(Mohamad Samsul, 2006: 180)

\section{b. Variabel Independen}

\section{1) Current Ratio}

Current Ratio adalah rasio likuiditas yang mengukur kemampuan perusahaan dalam menutup kewajiban lancarnya menggunakan aset lancar yang dimiliki. Menurut Brigham (2012: 134) Cara untuk mengukur rasio ini yaitu sebagai berikut :

$$
\text { Current Ratio }=\frac{\text { Aset Lancar }}{\text { Kewajiban Lancar }}
$$

\section{2) Inventory Turnover}

Inventory Turnover adalah rasio manajemen aset yang mengukur seberapa sering persedian yang dimiliki perusahaan mampu dikonversi menjadi penjualan. Menurut Wild (2005: 200) cara untuk mengukur ITO yaitu sebagai berikut :

Inventory Turnover $=\frac{\text { Harga pokok penjualan }}{\text { Rata-rata persediaan }}$

\section{3) Time Interest Earned}

Time Interest Earned atau sering juga disebut interest coverage ratio adalah salah satu rasio leverage yang mengukur sampai sejauh mana laba operasi mampu menutupi biaya bunga tahunanya. Menurut Brigham (2012: 144) cara untuk mengukur rasio ini yaitu dengan rumus berikut:

$$
\text { Time Interest Earned }=\frac{\text { EBIT }}{\text { Beban bunga }}
$$

\section{4) Return On Equity}

Return On Equity (ROE) adalah rasio profitabilitas yang mengukur tingkat laba dibandingkan dengan ekuitas saham biasa. Semakin tinggi ROE yang dihasilkan oleh suatu perusahaan maka akan meningkatkan kemakmuran para pemegang saham perusahaan. Menurut Brigham (2006: 109) cara untuk mengukur ROE adalah sebagai berikut :

$$
\mathrm{ROE}=\frac{\text { Laba bersih }}{\text { Ekuitas biasa }}
$$




\section{JURNAL NOMINAL / VOLUME III NOMOR 2 / TAHUN 2014}

\section{Populasi dan Sampel}

Populasi yang digunakan untuk penelitian ini adalah perusahaan sektor barang konsumsi yang terdaftar di BEI tahun 2009-2012. Populasi penelitian ini terdiri dari 37 perusahaan. Berdasarkan kriteria-kriteria yang telah ditatapkan dari 37 perusahaan sektor barang konsumsi yang terdaftar di Bursa Efek Indonesia periode 2009 -2012 terdapat 17 perusahaan yang layak dijadikan sampel, sehingga dalam 4 tahun terdapat 68 data pengamatan. Dari 68 data penelitian tersebut kemudian dikurangi dengan nilai yang terlalu ekstrim, sehingga akhirnya hanya 14 perusahaan atau 54 data pengamatan yang digunakan sebagai sampel.

\section{Teknik Pengumpulan Data}

Penelitian ini menggunakan teknik pengumpulan data berupa metode dokumentasi. Data yang dikumpulkan yaitu berupa laporan keuangan perusahaan manufaktur sektor barang konsumsi yang terdaftar di BEI tahun 2009-2012 dan data terkait yang berfungsi untung menghitung variabel dependen maupun independen.

\section{Teknik Analisis Data}

\section{a. Uji Asumsi Klasik \\ 1) Uji Normalitas}

Uji normalitas digunakan untuk mengetahui apakah variabel dalam penelitian, baik itu dependen maupun independen berdistribusi normal, mendekati normal atau tidak (Husein, 2001: 181). Pengujian normalitas data dilakukan dengan uji Kolmogorov Smirnov. Dalam Uji Kolmogorov Smirnov data dikatakan berdistribusi normal apabila nilai signifikansi pada hasil uji Kolmogorov Smirnov > 5\% (Imam Ghozali, 2011: 164).

\section{2) Uji Linearitas}

Uji linearitas adalah pengujian yang bertujuan untuk mengetahui atau memastikan apakah data yang digunakan untuk analisis regresi sesuai dengan garis linear atau tidak. Perhitungan statistik yang digunakan untuk menguji linearitas dalam penelitian ini yaitu menggunakan uji lagrange multiplier.

\section{3) Uji Multikolinearitas}

Uji multikolinieritas bertujuan untuk menguji apakah dalam model regresi ditemukan adanya korelasi antar variabel bebas (Husein, 2001: 177). Mendeteksi adanya multikolinieritas dapat digunakan nilai tolerance dan varian inflation factor (VIF) sebagai tolak ukur.

\section{4) Uji Autokorelasi}

Autokorelasi adalah korelasi antara sesama urutan pengamatan dari waktu ke waktu (Husein, 2001: 143). Untuk mengetahui adanya autokorelasi akan dilakukan Uji Durbin-Watson.

\section{5) Uji Heteroskedastisitas}

Uji heteroskedastisitas dilakukan untuk mengetahui apakah pada model regresi 
terjadi ketidaksamaan varian dari residual suatu pengamatan ke pengamatan lain (Husein, 2001: 179). Cara untuk memastikan bahwa model regresi tidak terjadi heteroskedastisitas adalah dengan menggunakan uji Glejser.

\section{b. Uji Hipotesis}

1) Analisis Regresi Linear Sederhana

Analisis regresi linear sederhana digunakan untuk mengetahui pengaruh varaiabel independen secara parsial terhadap variabel dependen. Menurut Sugiyono (2007:261) Regresi sederhana alat statistik yang didasarkan pada hubungan fungsional ataupun kausal variabel independen dengan satu variabel dependen. Uji ini digunakan untuk menguji hipoesis pertama sampai keempat, yaitu:

H1 : Current Ratio berpengaruh positif terhadap Harga Saham pada perusahaan manufaktur sektor barang konsumsi yang terdaftar di BEI periode 2009-2012.

$\mathrm{H} 2$ : Inventory Turnover berpengaruh positif terhadap Harga Saham pada perusahaan manufaktur sektor barang konsumsi yang terdaftar di BEI periode 2009-2012.

H3 : Time Interest Earned berpengaruh positif terhadap Harga Saham pada perusahaan manufaktur sektor barang konsumsi yang terdaftar di BEI periode 2009-2012 .
H4 : Return On Equity berpengaruh positif terhadap Harga Saham pada perusahaan manufaktur sektor barang konsumsi yang terdaftar di BEI periode 2009-2012.

\section{2) Analisis Regresi Linear Berganda}

Analisis Regresi linear berganda adalah analisis yang digunakan untuk mengetahui pengaruh secara bersama-sama variabel independen yang berjumlah dua atau lebih terhadap satu variabel dependen. Analisis ini digunakan untuk menguji hipotesis kelima, yaitu :

H5 : Current Ratio, Inventory Turnover, Time Interest Earned dan Return On Equity secara simultan berpengaruh terhadap Harga Saham pada perusahaan manufaktur sektor barang konsumsi yang terdaftar di BEI periode 2009-2012.

HASIL PENELITIAN DAN PEMBAHASAN

\section{Hasil Uji Asumsi Klasik}

a. Uji Normalitas

Tabel 1. Uji Normalitas Data

\begin{tabular}{llll}
\hline & N & $\begin{array}{l}\text { Kolmogorov- } \\
\text { Smirnov Z }\end{array}$ & $\begin{array}{l}\text { Asymp. } \\
\text { Sig. (2- } \\
\text { tailed) }\end{array}$ \\
& & & 0,000 \\
\hline $\begin{array}{l}\text { Harga } \\
\text { Saham }\end{array}$ & 54 & 2,055 & \\
\hline CR & 54 & 0,8310 & 0,495 \\
\hline
\end{tabular}


JURNAL NOMINAL / VOLUME III NOMOR 2 / TAHUN 2014

\begin{tabular}{llll}
\hline ITO & 54 & 1,120 & 0,163 \\
\hline TIE & 54 & 2,122 & 0,000 \\
\hline ROE & 54 & 0,917 & 0,370 \\
\hline
\end{tabular}

b. Uji Linearitas

Tabel 3.Hasil Uji Linearitas

\begin{tabular}{|l|c|c|c|c|}
\hline $\begin{array}{l}\text { Mod } \\
\text { el }\end{array}$ & $\mathrm{R}$ & $\begin{array}{c}\mathrm{R} \\
\text { Squ } \\
\text { are }\end{array}$ & $\begin{array}{c}\text { Adjus } \\
\text { ted R } \\
\text { Squar } \\
\mathrm{e}\end{array}$ & $\begin{array}{c}\text { Std. Error } \\
\text { of the } \\
\text { Estimate }\end{array}$ \\
\hline 1 &, 636 &, 405 &, 356 & 1,26485 \\
$\mathrm{a}$ & & \\
\hline
\end{tabular}

Tabel 2. Uji Normalitas Setelah Data ditransformasi

$\begin{array}{ccc}\mathrm{N} & \text { Kolmogorov- } & \text { Asymp. } \\ \text { Smirnov Z } & \text { Sig. (2- } \\ & \text { tailed) }\end{array}$

\begin{tabular}{llll}
\hline Harga & 54 & 0,698 & 0,715
\end{tabular}

Saham

\begin{tabular}{llll}
\hline CR & 54 & 0,544 & 0,929 \\
\hline ITO & 54 & 1,023 & 0,246 \\
\hline TIE & 54 & 0,938 & 0,343 \\
\hline ROE & 54 & 0,895 & 0,399
\end{tabular}

Dari tabel 2 diatas dapat terlihat bahwa semua variabel telah berdistribusi normal karena nilai signifikansi semua variabel lebih besar dari 0,05.

Dari tabel diatas dapat dilihat bahwa terdapat variabel yang tidak berdistribusi normal (Harga Saham dan TIE) karena nilai signifikasinya lebih kecil dari 0,005. Oleh karena itu semuan variabel ditransformasi kedalam logaritma natural.

Berdasarkan tabel di atas diperoleh nilai $\mathrm{R}^{2}$ sebesar 0,405, maka besarnya $\mathrm{C}^{2}$ yaitu $=\mathrm{n} \times \mathrm{R}^{2}$ $=54 \times 0,405=21,87$. Dengan demikian $C^{2}$ hitung $(21,87)<\mathrm{C}^{2}$ tabel (72.153) sehingga dapat disimpulkan bahwa model regresi tersebut linear.

\section{c. Uji Multikolinearitas}

Tabel 4. Hasil Uji Multikolinearitas

\begin{tabular}{|c|c|c|c|}
\hline & \multicolumn{2}{|c|}{ Collinearity Statistics } \\
\hline & & Tolerance & VIF \\
\hline & $\mathrm{CR}$ & 0,824 & 1,213 \\
\hline & ITO & 0,771 & 1,297 \\
\hline & TIE & 0,378 & 2,642 \\
\hline & ROE & 0,387 & 2,582 \\
\hline & \multicolumn{3}{|c|}{ Dependent Variable: Harga Saham } \\
\hline
\end{tabular}

Dari tabel di atas dapat dilihat bahwa nilai VIF semua variabel kurang dari 10 sehingga dapat disimpulkan bahwa tidak terjadi masalah multikolinearitas. 
JURNAL NOMINAL / VOLUME III NOMOR 2 / TAHUN 2014

\section{d. Uji Autokorelasi}

Tabel 5. Hasil Uji Autokorelasi

\begin{tabular}{|c|c|c|c|c|c|}
\hline $\begin{array}{l}\text { Mo } \\
\text { del }\end{array}$ & $\mathrm{R}$ & $\begin{array}{c}\mathrm{R} \\
\text { Squ } \\
\text { are }\end{array}$ & $\begin{array}{c}\text { Adjusted } \\
\text { R } \\
\text { Square }\end{array}$ & $\begin{array}{c}\text { Std. } \\
\text { Error } \\
\text { of the } \\
\text { Estima } \\
\text { te }\end{array}$ & $\begin{array}{l}\text { Dur } \\
\text { bin- } \\
\text { Wat } \\
\text { son }\end{array}$ \\
\hline 1 & $\begin{array}{r}.63 \\
6^{\mathrm{a}}\end{array}$ & .405 & .356 & $\begin{array}{r}1.2648 \\
5\end{array}$ & .775 \\
\hline
\end{tabular}

a. Predictors: (Constant), CR, ITO,TIE,ROE

b. Dependent Variable: Harga Saham

Menurut kriteria Danang sunyoto (2007: 105), sebuah model regresi tidak terjadi autokorelasi jika nilai Durbin-Watson terletak diantara -2 dan $+2(-2 \leq \mathrm{DW} \leq+2)$. Karena nilai durbin watson sebesar pada tabel diatas sebesar 0,755 terletak diantara 2 dan $+2(-2 \leq 0,775 \leq+2)$, maka dapat disimpulkan bahwa tidak terdapat autokorelasi.

\section{e. Uji Heteroskedastisitas}

Tabel 6. Hasil Uji Heteroskedastisitas

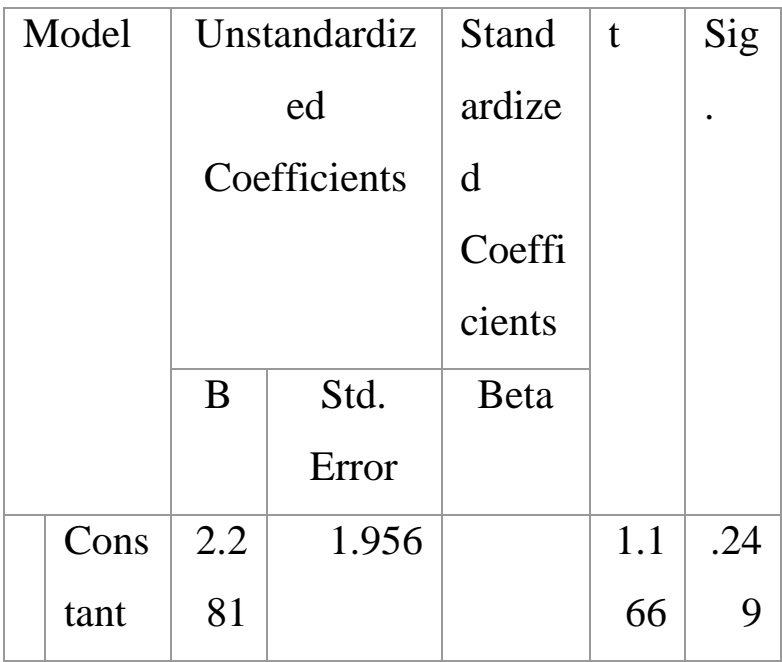

\begin{tabular}{|l|r|r|r|r|r|}
\hline CR & - & .378 & -.150 & - & .30 \\
& .39 & & & 1.0 & 8 \\
& 0 & & & 30 & \\
\hline ITO & .19 & .238 & .122 & .81 & .42 \\
& 2 & & & 0 & 2 \\
\hline TIE & - & .215 & -.174 & - & .42 \\
& .17 & & & .80 & 3 \\
& 4 & & & 9 & \\
\hline ROE & .31 & .182 & .361 & 1.6 & .09 \\
& 0 & & & 98 & 6 \\
\hline
\end{tabular}

Hasil uj glejser diatas menunjukan bahwa model regresi tidak terjadi gejala heteroskedastisitas. Hal tersebut dibuktikan dengan nilai signifikansi masing-masing variabel lebih besar dari 0,05.

\section{Hasil Uji Hipotesis}

a. Hasil Analisis Regresi Linear Sederhana

Tabel 7. Ringkasan Hasil Regresi Linear Sederhana.

\begin{tabular}{|c|c|c|c|c|}
\hline Keterangan & $\mathrm{CR}$ & ITO & TIE & ROE \\
\hline \multirow[t]{2}{*}{ Konstanta } & - & 5,831 & 2,933 & 3,211 \\
\hline & 3,791 & & & \\
\hline Koefisien & 1,676 & - & 1,176 & 0,799 \\
\hline regresi & & 0,584 & & \\
\hline $\mathrm{r}$ & 0,324 & 0,186 & 0,590 & 0,467 \\
\hline$r^{2}$ & 0,105 & 0,035 & 0,348 & 0,218 \\
\hline \multirow[t]{2}{*}{$t_{\text {hitung }}$} & 2,469 & - & 5,268 & 3,811 \\
\hline & & 1,365 & & \\
\hline$t_{\text {tabel }}$ & 1,675 & 1,675 & 1,675 & 1,675 \\
\hline sig & 0,017 & 0,178 & 0,000 & 0,000 \\
\hline
\end{tabular}


Variabel dependen: Harga Saham

\section{b. Hasil Analisis Regresi Linear Berganda}

Tabel 8. Ringkasan Hasil Regresi Linear Berganda.

\begin{tabular}{ll}
\hline Keterangan & $\begin{array}{l}\text { CR,ITO, TIE } \\
\text { dan ROE }\end{array}$ \\
\hline Konstanta & 1,008 \\
\hline Koefisien & $\mathrm{CR}=0,54 ; \mathrm{ITO}$ \\
regresi & $-0,713 ; \mathrm{TIE}=$ \\
& 0,$683 ; \mathrm{ROE}=$ \\
& 0,463 \\
\hline $\mathrm{R}$ & 0,636 \\
\hline $\mathrm{R}^{2}$ & 0,405 \\
\hline $\mathrm{F}_{\text {hitung }}$ & 8,332 \\
\hline $\mathrm{F}_{\text {tabel }}$ & 2,56 \\
\hline sig & 0,000 \\
\hline Variabel & \\
\hline
\end{tabular}

Variabel Dependen : Harga Saham

Hasil perhitungan sumbangan prediktor (sumbangan relatif dan sumangan efektif)menunjukan nilai sebagai berikut

Tabel 6. Perhitungan Sumbangan Prediktor

\begin{tabular}{lllll}
\hline $\begin{array}{l}\text { Keter } \\
\text { angan }\end{array}$ & $\mathrm{X} 1$ & $\mathrm{X} 2$ & $\mathrm{X} 3$ & $\mathrm{X} 4$ \\
\hline SR & 46,62 & 17,70 & 19,19 & 16,49 \\
& $\%$ & $\%$ & $\%$ & $\%$ \\
\hline SE & 18,88 & $7,17 \%$ & $7,77 \%$ & $6,67 \%$ \\
& $\%$ & & & \\
\hline
\end{tabular}

\section{Pembahasan Hasil Penelitian}

a. Pengaruh Current Ratio terhadap

\section{Harga Saham}

Variabel Current Ratio (CR) berpengaruh positif dan signifikan terhadap Harga Saham. Hal tersebut dibuktikan dengan nilai koefisien regresi sebesar 1,676, nilai $t_{\text {hitung }}$ yang lebih besar dibanding $t_{\text {tabel }}$ pada tingkat signifikansi $0,05 \quad(2,469>$ 1,675) dan nilai signifikansi 0,017 menunjukan nilai yang lebih kecil dari nilai signifikansi yang ditentukan, yaitu 0,05. Berdasarkan hal tersebut dapat disimpulkan bahwa hipotesis pertama diterima.

Hasil Penelitian ini tidak sejalan dengan hasil penelitian yang dilakukan oleh Adelia Violeta Ketaren (2011) yang berjudul "Pengaruh Current Ratio, Debt to Equity Ratio, Total Assets Turn Over, Return On Equity, dan Earning Per Share terhadap Harga Saham pada Perusahaan Barang Konsumsi yang Terdaftar di Bursa Efek Indonesia". Hasil penelitian tersebut menyatakan bahwa tidak terdapat pengaruh yang signifikan antara Current Ratio terhadap Harga Saham. Perbedaan hasil penelitian ini bisa dikarenakan oleh jangka waktu penelitian yang tidak sama dimana dalam penelitian ini mengambil 4 tahun sedangkan penelitian yang dilakukan Adelia Violeta Ketaren hanya dalam waktu tiga tahun. Selain itu, bisa juga disebabkan oleh cara perhitungan Harga Saham yang berbeda, dimana dalam penelitian ini 


\section{JURNAL NOMINAL / VOLUME III NOMOR 2 / TAHUN 2014}

menggunakan Indeks Harga Saham Individual sedangkan pelitian Violeta menggunakan Closing Price.

Penelitian ini sejalan dengan teori yang dikemukakan Brigham (2012: 150) bahwa Harga Saham kemungkinan akan tinggi sesuai yang diperkirakan jika nilai dari rasio likuiditas, manajemen aset, manajemen utang dan rasio profitabilitas terlihat baik dan kondisi tersebut berjalan terus secara stabil. Current Ratio merupakan rasio likuditas yang membandingkan aset lancar dengan utang lancar. Jika Current Ratio baik maka kemampuan perusahaan akan semakin baik dalam mencukupi hutang jangka pendeknya dan terhindar dari masalah likuiditas. Hal itulah yang akhirnya membuat investor tertarik dan berakibat pada naiknya Harga Saham.

\section{b. Pengaruh Inventory Turnover terhadap Harga Saham}

Variabel Inventory Turnover (ITO) berpengaruh negatif dan tidak signifikan terhadap Saham. Hal tersebut dibuktikan dengan nilai koefisien regresi $-0,584$, nilai $t_{\text {hitung }}$ yang lebih kecil dari $t_{\text {tabel }}$ dengan tingkat signifikansi 5\%, dimana $t_{\text {hitung }}$ sebesar 1,365 dan $t_{\text {tabel }}$ sebesar 1,675 (1,365 $<$ 1,675). Selain itu, nilai signifikansi sebesar 0,178 menunjukan nilai yang lebih besar dari nilai signifikansi yang ditentukan, yaitu 0,05. Berdasarkan hal tersebut dapat disimpulkan bahwa hipotesis kedua ditolak.
Hasil penelitian ini kurang sejalan dengan penelitian yang dilakukan oleh Dady Suhadi (2009), yang berjudul "Pengaruh Rasio Aktivitas, Rasio Profitabilitas, Rasio Laverage, dan Rasio Penilaian terhadap Harga Saham Perusahaan Food and Beverage". Pada penelitian tersebut menunjukan bahwa ITO berpengaruh positif dan signifikan terhadap Harga Saham. Perbedaan hasil dari penelitian ini dengan penelitian yang dilakukan oleh Dady Suhadi bisa disebabkan oleh perbedaan luas sektor. Pada penelitian ini sektor yang dipilih adalah sektor barang konsumsi, sedangkan penelitian Dady Suhady hanya menggunkan subsektor makanan dan minuman, dimana subsektor tersebut hanya sebagian kecil dari perusahaan sektor barang konsumsi yang terdaftar di BEI.

Hasil Penelitian ini juga tidak sejalan dengan teori yang dikemukakan oleh Brigham (2012: 150) bahwa Harga Saham kemungkinan akan tinggi sesuai yang diperkirakan jika nilai dari rasio likuiditas, manajemen aset, manajemen utang dan rasio profitabilitas terlihat baik dan kondisi tersebut berjalan terus secara stabil. Inventory Turnover merupakan rasio manajemen asset yang menghitung seberapa sering persediaan mampu berputar dalam satu tahun. Jika Inventory Turnover semakin tinggi maka kemungkinan laba yang dihasilkan akan tinggi pula. Disisi lain, 


\section{JURNAL NOMINAL / VOLUME III NOMOR 2 / TAHUN 2014}

apabila persediaan terlalu sering berputar juga bisa menyebabkan masalah likuiditas, bisa juga mengakibatkan ketidakmampuan perusahaan mencapai target penjualan karena minimnya persediaan pada perusahaan tersebut. Oleh karena itu perputaran persediaan yang tinggi tidak selamanya baik, terkadang justru mengakibatkan masalah.

\section{c. Pengaruh Time Interest Earned terhadap Harga Saham}

Variabel Time Interest Earned (TIE) berpengaruh positif dan signifikan terhadap Saham. Hal tersebut dibuktikan dengan nilai koefisien regresi sebesar 1,176 dan nilai thitung yang lebih besar dari tabel dengan tingkat signifikansi 5\%, dimana $t_{\text {hitung }}$ sebesar 2,568 dan $t_{\text {tabel }}$ sebesar1,675 (1,365 $<$ 1,675). Selain itu, nilai signifikansi sebesar 0,000 menunjukan nilai yang lebih kecil dari nilai signifikansi yang ditentukan, yaitu 0,05. Berdasarkan hal tersebut dapat disimpulkan bahwa hipotesis ketiga diterima.

Hasil Penelitian ini Sejalan dengan penelitian yang dilakukan oleh Moh Fahmi Rizka (2012), yang berjudul "Pengaruh Struktur Modal terhadap Harga Saham pada Perusahaan Manufaktur yang terdaftar di Bursa Efek Indonesia". Pada penelitian tersebut menunjukan bahwa ada pengaruh positif dan signifikan terhadap Harga Saham. Hasil Penelitian ini juga sejalan dengan teori yang dikemukakan oleh Brigham (2012: 150) bahwa Harga Saham kemungkinan akan tinggi sesuai yang diperkirakan jika nilai dari rasio likuiditas, manajemen aset, manajemen utang dan rasio profitabilitas terlihat baik dan kondisi tersebut berjalan terus secara stabil. Rasio TIE merupakan leverage (manajemen utang) yang mengukur kemampuan perusahaan membayar beban bunga atas hutanghutangnya. TIE yang tinggi menandakan bahwa perusahaan semakin mampu untuk membayar beban bunganya. Kemampuan perusahaan tersebut membuat perusahaan semakin terhindar dari resiko gagal bayar, yang bisa berujung pada kebangkrutan. Hal ini lah yang membuat investor lebih tertarik pada saham perusahaan dengan TIE tinggi dan akhirnya berujung pada naiknya harga saham perusahaan tersebut.

\section{d. Pengaruh Return On Equity terhadap Harga Saham}

Variabel Return On Equity (ROE) berpengaruh positif dan signifikan terhadap Harga Saham. Hal tersebut dibuktikan dengan nilai koefisien regresi sebesar 0,799 dan nilai thitung yang lebih besar dari $t_{\text {tabel }}$ dengan tingkat signifikansi 5\%, dimana

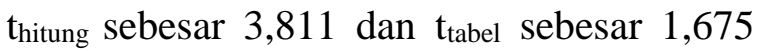
$(3,811<1,675)$. Selain itu, nilai probabilitas signifikansi sebesar 0,000 menunjukan nilai yang lebih kecil dari nilai signifikansi yang ditentukan, yaitu 0,05. Berdasarkan hal 
tersebut dapat disimpulkan bahwa hipotesis keempat diterima.

Hasil penelitian ini sejalan dengan penelitian yang dilakukan oleh Rescyana Putri Hutami (2012) yang berjudul "Pengaruh Devident Per Share, Return On Equity dan Net Profit Margin terhadap Harga Saham Perusahaan Industri Manufaktur yang tercatat di Bursa Efek Indonesia Periode 2006-2010”. Hasil penelitian tersebut menunjukan bahwa variabel Return On Equity berpengaruh positif dan signifikan. Disisi lain,penelitian ini tidak sejalan dengan penelitian yang dilakukan Adelia Violeta Kataren (2011) yang berjudul "Pengaruh Current Ratio, Debt to Equity Ratio, Total Assets Turn Over, Return On Equity, dan Earning Per Share terhadap Harga Saham pada Perusahaan Barang Konsumsi yang Terdaftar di Bursa Efek Indonesia" Pada penelitian tersebut menunjukan bahwa ROE tidak berpengaruh signifikan terhadap Harga Saham.

Hasil penelitian ini sejalan dengan teori yang dikemukakan Mohammad Samsul (2006) yang mengatakan bahwa faktor mikroekonomi berupa ROE berpengaruh terhadap Harga Saham. Hasil penelitian ini juga sejalan dengan teori yang dikemukakan Brigham (2012) bahwa ROE merupakan rasio akuntansi yang paling penting dan jika nilainya baik dan berjalan terus secara stabil akan membuat Harga Saham tinggi. Rasio
ROE menunjukan tingkat pengembalian ekuitas. Ketika seorang investor berinvestasi tentu mengharapkan pengembalian atas apa yang telah diinvestasikan. Rasio ini menggambarkan seberapa baik perusahaan mampu mengembalikan apa yang telah diinvestasikan investor tersebut. Oleh karena itu semakin tinggi ROE akan semakin menarik investor dan berujung pada kenaikan Harga Saham. Hal tersebut juga telah terbukti sesuai dengan hasil penelitian ini.

\section{e. Pengaruh Current Ratio, Inventory Turnover, Time Interest Earned dan Return On Equity terhadap Harga Saham}

Variabel Current Ratio, Inventory Turnover, Time Interest Earned dan Return On Equity secara simultan berpengaruh signifikan terhadap Harga Saham. Hal ini dibuktikan dibuktikan dengan nilai $F_{\text {hitung }}$ yang lebih besar dari $F_{\text {tabel }}$ pada tingkat signifikansi 5\%, dimana $F_{\text {hitung }}$ sebesar 8,332 dan $F_{\text {tabel }}$ sebesar 2,56. Selain itu, nilai probabilitas signifikansi sebesar 0,000 juga menunjukan nilai yang lebih kecil dari nilai yang telah ditentukan yaitu $0,05(0,000<$ $0,05)$.

Sumbangan relatif dan efektif setiap variabel nilainya bervariasi. Variabel Current Ratio memiliki nilai sumbangan relatif sebesar $46,62 \%$ dan sumbangan efektif sebesar $18,88 \%$. Variabel Inventory 
Turnover memiliki nilai sumbangan relatif sebesar $17,70 \%$ dan sumbangan efektif sebesar $7,17 \%$. Variabel Time Interest Earned memiliki nilai sumbangan relatif sebesar 19,19\% dan sumbangan efektif sebesar 7,77\%. Variabel Return On Equity memiliki nilai sumbangan relatif sebesar $16,49 \%$ dan sumbangan efektif sebesar $6,68 \%$.

Berdasarkan hasil penelitian ini dapat disimpulkan bahwa hipotesis yang diajukan sejalan dengan hasil penelitian. Jika secara parsial tidak semua variabel berpengaruh terhadap Harga Saham, namun secara simultan semua variabel bebas yang diajukan berpengaruh terhadap Harga Saham Perusahaan manufaktur sektor barang konsumsi yang terdaftar di BEI periode 2009-2012 (hipotesis kelima diterima).

\section{SIMPULAN DAN SARAN}

\section{Kesimpulan}

a. Current Ratio (CR) berpengaruh positif dan signifikan terhadap Harga Saham pada perusahaan manufaktur sektor barang konsumsi yang terdaftar di BEI 2009-2012. Hal tersebut dibuktikan dengan nilai koefisien regresi sebesar 1,676 dan nilai thitung yang lebih besar dari tabel dengan tingkat signifikansi $5 \%$, dimana thitung sebesar 2,469 dan $t_{\text {tabel }}$ sebesar 1,675 (2,496> 1,675). Selain itu, nilai probailitas signifikansi sebesar
0,017 menunjukan nilai yang lebih kecil dari nilai signifikansi yang ditentukan, yaitu 0,05 .

b. Inventory Turnover (ITO) berpengaruh negatif dan tidak signifikan terhadap Harga Saham pada perusahaan manufaktur sektor barang konsumsi yang terdaftar di BEI 2009-2012. Hal tersebut dibuktikan dengan nilai koefisien regresi sebesar $-0,584$ dan nilai $t_{\text {hitung }}$ yang lebih kecil dari $t_{\text {tabel }}$ dengan tingkat signifikansi 5\%, dimana $t_{\text {hitung }}$ sebesar 1,365 dan $t_{\text {tabel }}$ sebesar 1,675 (1,365 < 1,675). Selain itu, nilai probailitas signifikansi sebesar 0,178 menunjukan nilai yang lebih besar dari nilai signifikansi yang ditentukan, yaitu 0,05 .

c. Time Interest Earned (TIE) berpengaruh positif dan signifikan terhadap Harga Saham pada perusahaan manufaktur sektor barang konsumsi yang terdaftar di BEI 2009-2012. Hal tersebut dibuktikan dengan nilai koefisien regresi sebesar 1,176 dan nilai $t_{\text {hitung }}$ yang lebih besar dari $t_{\text {tabel }}$ dengan tingkat signifikansi 5\%, dimana thitung sebesar 2,568 dan $t_{\text {tabel }}$ sebesar 1,675 $(1,365<1,675)$. Selain itu, nilai probailitas signifikansi sebesar 0,000 menunjukan nilai yang lebih kecil dari nilai signifikansi yang ditentukan, yaitu 0,05 . 


\section{JURNAL NOMINAL / VOLUME III NOMOR 2 / TAHUN 2014}

d. Return On Equity (ROE) berpengaruh positif dan signifikan terhadap Harga Saham pada perusahaan manufaktur sektor barang konsumsi yang terdaftar di BEI 2009-2012. Hal tersebut dibuktikan dengan nilai koefisien regresi sebesar 0,799 dan nilai thitung yang lebih besar dari $t_{\text {tabel }}$ dengan tingkat signifikansi $5 \%$, dimana $t_{\text {hitung }}$ sebesar 3,811 dan $t_{\text {tabel }}$ sebesar 1,675 $(3,811<1,675)$. Selain itu, nilai probailitas signifikansi sebesar 0,000 menunjukan nilai yang lebih kecil dari nilai signifikansi yang ditentukan, yaitu 0,05 .

e. Current Ratio, Inventory Turnover, Time Interest Earned dan Return On Equity secara simultan berpengaruh signifikan terhadap Harga Saham pada perusahaan manufaktur sektor barang konsumsi yang terdaftar di BEI periode 2009-2012. Hal ini dibuktikan dibuktikan dengan nilai $F_{\text {hitung }}$ yang lebih besar dari $F_{\text {tabel }}$ pada tingkat signifikansi $5 \%$, dimana $F_{\text {hitung }}$ sebesar 8,332 dan $\mathrm{F}_{\text {tabel }}$ sebesar 2,56. Selain itu, nilai probabilitas signifikansi sebesar 0,000 juga menunjukan nilai yang lebih kecil dari nilai yang telah ditentukan yaitu $0,05(0,000<0,05)$.

\section{Saran}

Berdasarkan hasil penelitian dan kesimpulan diatas, maka diberikan saran sebagai berikut:

1. Bagi Investor

Investor hendaknya lebih memperhatikan nilai Current Ratio (CR), Time Interest Earned (TIE) dan Return On Equity (ROE) sebagai alat pertimbangan dalam memilih perusahaan sebelum berinvestasi. Hal itu penting karena rasio-rasio tersebut terbukti berpegaruh terhadap Harga Saham sesuai dengan hasil dari penlitian ini.

2. Bagi Perusahaan

Perusahaan hendaknya memperhatikan Current Ratio (CR), Time Interest Earned (TIE) dan Return On Equity (ROE) agar semua rasio tersebut memiliki nilai yang baik. Hal itu penting karena telah terbukti apabila nilai-nilai rasio itu baik maka akan berpengaruh terhadap Harga Saham dan akan menarik minat Investor. Peningkatan ketiga variabel tersebut dapat dilakukan dengan cara seperti selalu memperhatikan posisi aset lancar dan hutang lancar sehingga likuiditas perusahaan yang diukur dengan Current Ratio selalu dalam keadaan yang baik, mengatur proporsi hutang sehingga beban bunganya tidak terlalu memberatkan, melakukan kegiatan 
operasi dengan cara memanfaatkan ekuitas yang ada seefisien mungkin sehingga selalu menghasilkan laba yang tinggi sehingga nilai rasio ROE juga akan baik.

3. Bagi Peneliti Selanjutnya

a. Menambah jumlah sampel atau populasi yang diteliti, tidak hanya terbatas pada sektor barang konsumsi.

b. Menambah rasio-rasio lain, baik itu rasio likuiditas, manajemen aset, leverage ataupun profitabilitas.

c. Menambah referensi baik itu penelitian maupun teori agar penelitian selanjutnya lebih baik.

\section{DAFTAR PUSTAKA}

Adelia Violeta Ketaren (2011). "Pengaruh Current Ratio, Debt to Equity Ratio, Total Assets Turn Over, Return On Equity, dan Earning Per Share terhadap Harga Saham pada Perusahaan Barang Konsumsi yang Terdaftar di Bursa Efek Indonesia”. Skripsi. Universitas Sumatera Utara.

BAPEPAM-LK. (2012) Factbook tahun 2011. Diambil dari: http://www.bapepam.go.id/pasar_mo dal/publikasi_pm/siaran_pers_pm/20 12/pdf/Factbook-Bapepam-LK2011.pdf, pada 10 februari 2014.
Brigham, Houston (2006). Dasar-dasar Manajemen Keuangan, edisi kesepuluh. Jakarta: Salemba Empat. (2012). Dasar-dasar Manajemen Keuangan, edisi kesepuluh. Jakarta: Salemba Empat.

Burhan,N.,Gunawan \& Marzuki.(2002) Statistik Terapan Untuk Penelitian Ilmu-Ilmu Sosial. Yogyakarta : Gajah Mada University Press.

Dady Suhadi (2009), yang berjudul "Pengaruh Rasio Aktivitas, Rasio Profitabilitas, Rasio Laverage, dan Rasio Penilaian terhadap Harga Saham Perusahaan Food and Beverage". Jurnal Informasi, Perpajakan, Akuntansi dan Keuangan Publik (Vol.4, No. I Januari 2009). Hal. 17-35.

Eduardus Tandelin, M. (2007). Analisis Investasi dan Manajemen Portofolio. Yogyakarta: BPFEYOGYAKARTA.

Husein Umar.(2001). Metode Penelitian untuk Skripsi dan Tesis bisnis. Jakarta: Rajawali pers.

Imam Ghozali. (2011). Aplikasi Analisis Multivariate dengan Program SPSS. Semarang: Badan Penerbit Universitas Diponegoro.

Jogiyanto Hartono, M. (2010). Teori portofolio dan analisis investasi. Yogyakarta: BPFE. 
Keown, Arthur J. et al. (2011). Manajemen

Keuangan: prinsip dan penerapan. Edisi 10, jilid 1. Jakarta: PT Indeks.

Lukman Syamsuddin. (2011). Manajemen

Keuangan Perusahaan: Konsep Aplikasi dalam Perencanaan, Pengawasan, dan Pengambilan Keputusan. Jakarta: Rajawali Pers.

Mohammad Samsul.(2006). Pasar Modal \& Manajemen Portofolio,Jakarta: Erlangga.

Mohd. Fahmi Rizka (2012), yang berjudul "Pengaruh Struktur Modal terhadap Harga Saham pada Perusahaan Manufaktur yang Terdaftar di Bursa Efek Indonesia”. Skripsi. Universitas Sumatera Utara.

Mudrajad Kuncoro.(2003). Metodologi riset untuk bisnis \& ekonomi, Bagaimana meneliti dan menulis tesis?. Jakarta :Erlangga.

Nor Hadi. (2013). Pasar Modal:Acuan teoritis dan praktis investasi di instrumen keuangan pasar modal. Yogyakarta: Graha Ilmu.

Nur Indriantoro dan Bambang Supomo.(2002) Metodologi penelitian bisnis. Yogyakarta: BPFE yogyakarta.

Rescya Putri Hutami (2012). "Pengaruh Devidend Per Share, Return On Equity dan Net Profit Margin Terhadap Harga Saham Perusahaan Industri Manufaktur yang Tercatat di
Bursa Efek Indonesia Periode 20062010”. Skripsi tidak diterbitkan.Universitas Negeri Yogyakarta

Suad Husnan.(2001). Dasar-dasar Teori Prtofolio dan Analisis Sekuritas. Yogyakarta: UPP AMP YKPN.

Sugiyono. (2008). Statistika Untuk Penelitian. Bandung: Alfabeta.

Sutrisno Hadi.(1994). Analisis Regresi. Yogyakarta: Andi Offset.

Tjiptono Darmaji \& H.M Fakhrudin. (2000).

Pasar Modal Indonesia Pendekatan

Tanya Jawab. Jakarta:Salemba Empat.

Walsh,Ciaran. (2004). Key Management Ratios: rasio-rasio manajemen penting penggerak dan pengendali bisnis. Jakarta: Erlangga.

Wild, Jhon J., Subramanyam, K.R.\& Halsey R.F.(2005). Analisis laporan keuangan. Jakarta: Salemba Empat.

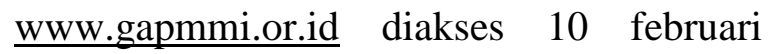
2014.

www.idx.co.id diakses tanggal 12 januari 2014

www.investor.co.id diakses 10 februari 2014.

www.tempo.co.id diakses 10 februari 2014 